\title{
Analisa Ketelitian Gerak Sumbu X Ekstruder Mesin Fused Deposition Modeling dan Kualitas Hasil 3D Printing Menggunakan Bahan Polylactic Acid (PLA)
}

\author{
A. T. Rohman, H.S.B. Rochardjo*, Herianto \\ Departemen Teknik Mesin dan Industri, Fakultas Teknik, Universitas Gadjah Mada. \\ JI. Grafika No. 2, Kompleks UGM, Yogyakarta 55281, Indonesia \\ E-mail: *heru-sbr@ugm.ac.id
}

\begin{abstract}
Abstrak
Fused Deposition Modeling (FDM) merupakan teknologi additive layer manufacturing (ALM) yang bekerja dengan cara ekstrusi material. Material yang digunakan adalah polylactid acid (PLA). Tantangan penggunaan teknologi FDM antara lain kualitas dimensi benda hasil uji printing. Oleh karena itu dilakukan penelitian yang bertujuan untuk mengetahui besar akurasi gerak ekstruder mesin FDM dan ketelitian dimensi benda hasil uji printing pada mesin FDM. Pengaruh optimasi kontrol pada mesin FDM akan dilihat pengaruhnya terhadap akurasi gerak mesin FDM dan ketelitian benda uji.

Penelitian dilakukan pada sumbu gerak ekstruder mesin FDM. Metode penelitian dengan cara pengukuran akurasi under no load pada mesin FDM dan divalidasi menggunakan pengukuran ketelitian dimensi hasil uji printing. Pengukuran under no load menggunakan laser interferometer sedangkan pengukuran dimensi benda uji printing menggunakan mesin CMM. Parameter kecepatan dan proses printing ditetapkan pada nilai tertentu. Optimasi kontrol dilakukan dengan penambahan step/ unit motor 80,1 dan 80,2.

Perbedaan hasil pengukuran under no load dan pengukuran ketelitian dimensi pada hasil printing banyak dipengaruhi oleh faktor shrinkage material. Kompensasi kontrol dapat meningkatkan ketelitian dimensi sebesar 0,145 mm. Mesin FDM yang diteliti dapat menghasilkan ketelitian dimensi produk sebesar $0,157 \mathrm{~mm}$ dengan nilai ketidakpastian dibawah $\pm 0.050 \mathrm{~mm}$.
\end{abstract}

Kata kunci : ketidakpastian pengukuran, FDM, shrinkage, kompensasi kontrol, step/ unit, under no load

\begin{abstract}
Fused Deposition Modeling (FDM) is an additive layer manufacturing (ALM) technology that works by material extrusion. The material used is polylactid acid (PLA). FDM technology has challenges in the quality and accuracy of product dimensions. Therefore, this research is conducted to determine the accuracy and repeatability of FDM machine and the benefit caused by FDM machine compensations.

The research is carried out on the FDM extruder axis. The study is conducted by accuracy and repeatability measurement under no load condition on the FDM machine by laser interferometer and then validated by dimensional accuracy measurements of the printing test dimensions using CMM. Velocity and process parameters are set at a certain value. Machine control compensation is conducted by adding 80.1 and 80.2 step/unit motor.
\end{abstract}


The differences between under no load measurement and the products dimensional accuracy of the printing results is largely influenced by the material shrinkage. Control compensation increase dimensional accuracy by $0.145 \mathrm{~mm}$. The FDM machine could produce an accuracy of product dimensions of $0.157 \mathrm{~mm}$ with uncertainty values under $+0.050 \mathrm{~mm}$.

Keywords : uncertainty, fdm, shrinkage, control compensation, step/unit, under no load

\section{PENDAHULUAN}

Additive manufacturing (AM) merupakan teknologi pembentukan material yang berbeda dengan teknologi substractive manufacturing yang menghilangkan material mentah menjadi komponen jadi. Dalam teknologi AM, material dibentuk berdasarkan lapis demi lapis atau disebut layer manufacturing (LM) menjadi bentuk 3D model atau diistilahkan sebagai Additive Layer Manufacturing (ALM).

Beberapa penelitian mengkaji dan memperoleh wawasan bahwa teknologi AM memiliki kemanfaatan potensi yang tinggi (Berman, 2012). Potensi keuntungannya antara lain berkurangnya biaya tooling, mengurangi scrap permesinan dan mengurangi dampak kerusakan lingkungan dengan asumsi bahwa penerapan AM tidak hanya untuk pembuatan prototype namun juga untuk produk konsumsi masyarakat (Schniederjans dan Yalcin, 2018). Keuntungan dalam penggunaan teknologi AM lainnya adalah peningkatan keragaman produk dan jumlah produksi yang rendah dengan kecepatan produksi yang tinggi dan pelayanan konsumen yang tinggi. Aplikasi dari AM sudah diterapkan dalam berbagai bidang antara lain pendidikan, mekanik, otomotif, aerospace, robotic, kelautan, arsitek, medis dan industri farmasi. Dalam industri farmasi sudah dimulai pembuatan obat oral menggunakan $3 \mathrm{~d}$ printing dengan variasi geometrik, dimensi dan warna. Airbus memproduksi lebih dari 1.000 komponen menggunakan mesin fused deposition modelling (FDM) dengan material resin ULTEMTM 9085 untuk dipasang pada pesawat A 350 XWB karena memiliki keunggulan dalam akurasi/ketelitian dimensi dan kestabilan material. Produk medis intra-uterine device (IUD) juga diproduksi menggunaan mesin $3 \mathrm{~d}$ printing FDM. (Sadia dkk, 2017). Kelebihan pada AM ternyata tidak selaras dengan ketelitian produk AM (Dimitrov dkk, 2006). Selain itu faktor lain yang masih menjadi kendala pada produk ALM adalah kualitas dimensi seperti ketelitian geometrik, mampu ulang dan kehalusan permukaan.

Sebagian besar penelitian kualitas produk AM adalah dengan cara pengukuran benda uji hasil proses AM melalui perhitungan nilai penyimpangan dimensi, geometrik dan kualitas kondisi permukaan. Namun, penelitian yang sudah ada lebih kepada optimasi pada parameter proses AM. Salah satu penelitian parameter utama adalah dimensi komponen, temperatur ekstruder, orientasi printing dan layer thickness yang berpengaruh terhadap akurasi dimensi produk AM (Lim dkk, 2016). Cajal (2016) melakukan penelitian volumetric error pada mesin polyjet Objet350V 3D printer dengan cara pengukuran benda uji hasil printing menggunakan mesin CMM dan menganalisa systematic error yang terjadi pada mesin tersebut. Penelitian kualitas hasil AM berdasarkan kondisi mesin masih belum banyak dilakukan. Oleh karena itu pada penelitian ini akan dilakukan pengukuran akurasi mesin FDM kemudian dilakukan validasi menggunakan pengukuran pada benda uji hasil printing AM pada mesin tersebut. Peningkatan kualitas hasil AM akan dilakukan dengan cara kompensasi kontrol pada mesin FDM. 


\section{METODE PENELITIAN}

Penelitian diawali dengan penentuan jenis pengukuran akurasi mesin FDM, penentuan parameter pengukuran yang digunakan pada pengukuran under no load penentuan parameter proses printing, pelaksanaan pengukuran mesin FDM, pembuatan benda uji printing, pengukuran ketelitian dimensi mesin, evaluasi ketelitian dimensi mesin dan optimasi step/unit motor. Obyek penelitian adalah sumbu gerak X (ekstruder) mesin FDM dengan spesifikasi sebagai berikut: motor stepper NEMA 17, penggerak timing belt GT2, pulley GT2 dan guide rod $8 \mathrm{~mm}$. Diameter nozzle ektruder adalah $0.4 \mathrm{~mm}$. Material yang digunakan adalah polylactide (PLA) dengan diameter penampang sebesar $1,75 \mathrm{~mm}$. Material PLA memiliki suhu kerja $180-200^{\circ} \mathrm{C}$, titik leleh $120-170$ ${ }^{\circ} \mathrm{C}$ dan titik softening $45-120{ }^{\circ} \mathrm{C}$ (Valerga dkk, 2018). Konfigurasi ekstruder sumbu X dapat dilihat pada Gambar 1.

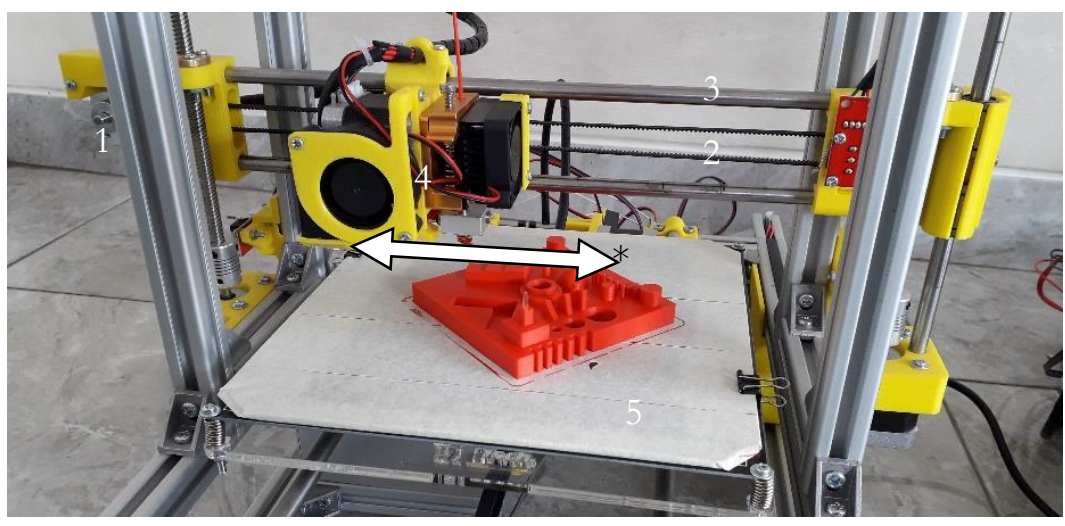

Keterangan gambar :

1. Motor stepper.

2. Timing belt.

3. Guide rod.

4. Ekstruder.

5. Bed FDM.

* Arah gerak ekstruder (sumbu X)

Gambar 1. Skema ekstruder sumbu X mesin FDM

\section{Peralatan yang digunakan}

1. Laser Interferometer Renishaw ML 10

Laser interferometer merupakan alat ukur berbasis laser dan optik yang memiliki resolusi dan akurasi yang sangat tinggi. Evaluasi yang dilakukan untuk mesin FDM adalah pengukuran akurasi posisi, backlash dan mampu ulang mesin FDM. Konfigurasi perangkat uji laser interferometer dapat dilihat pada Gambar 2. Spesifikasi laser interferometer dapat dilihat pada Tabel 1.

Tabel 1. Spesifikasi laser interferometer Renishaw ML10 (Begović dkk, 2014)

\begin{tabular}{llc}
\hline No & \multicolumn{1}{c}{ Spesifikasi } & Keterangan \\
\hline $\mathbf{1}$ & Spesifikasi laser & Hellium Neon $(\mathrm{HeNe})$ laser tube \\
$\mathbf{2}$ & Akurasi sistem & $0,5 \mathrm{ppm}$ \\
$\mathbf{3}$ & Akurasi frekuensi laser & $\pm 0,05 \mathrm{ppm}$ \\
$\mathbf{4}$ & Resolusi & $0,001 \mathrm{mikron}$ \\
$\mathbf{5}$ & Kecepatan maksimum & $4,0 \mathrm{~m} / \mathrm{detik}$ \\
$\mathbf{6}$ & Frekuensi & $50 \mathrm{kHz}$ \\
$\mathbf{7}$ & Range & $0-40 \mathrm{~meter}$ \\
$\mathbf{8}$ & Suhu operasi & $0-40^{\circ} \mathrm{C}$ \\
$\mathbf{9}$ & Kelembapan operasi & $0-95 \%$ (tanpa kondensasi) \\
\hline
\end{tabular}




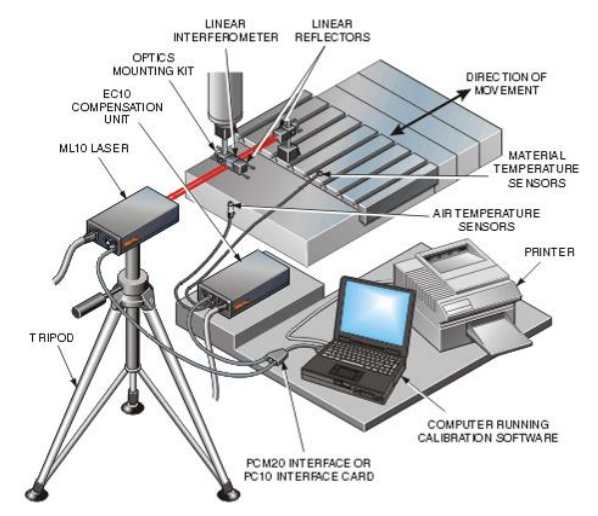

Gambar 2. Konfigurasi pengukuran laser interferometer (Begović dkk, 2014)

\section{Coordinate Measuring Machine (CMM)}

Mesin CMM dipilih dan digunakan untuk mengukur kualitas dimensi benda uji hasil printing. Pertimbangan dalam pemilihan CMM sebagai alat ukur adalah nilai error maksimum yang

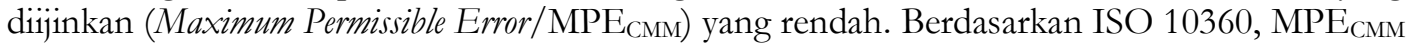
didefinisikan sebagai berikut

$$
\mathrm{MPE}_{\mathrm{CMM}} \quad: \pm(\mathrm{X}+\mathrm{L} / \mathrm{K})
$$

dengan $\mathrm{X}$ adalah tingkat akurasi mesin $\mathrm{CMM}$ dengan satuan $\mu \mathrm{m}, \mathrm{K}$ adalah konstanta dan $\mathrm{L}$ adalah panjang stroke sumbu mesin CMM dengan satuan mm. Mesin CMM yang digunakan

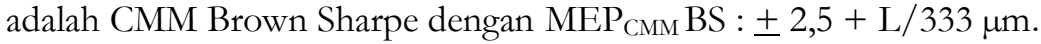

Sampel benda uji pada Gambar 3 menunjukkan cara pengambilan 9 titik data pada tiap posisi. Pengambilan data dilakukan secara point to point probe dan tidak dilakukan secara scanning. Point to point probing adalah pengambilan data pada permukaan satu demi satu. Sedangkan, scanning probe merupakan cara pengambilan data dengan cara mengikuti suatu permukaan atau selalu menempel sambil mengumpulkan titik koordinat permukaan tersebut. Point to point probe mempunyai nilai ketidakpastian hasil pengukuran yang lebih kecil dibanding dengan metode scanning probe.
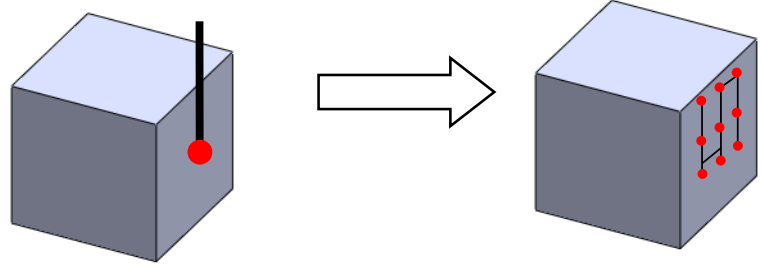

Gambar 3. Sampling pengambilan data per posisi.

Pengukuran benda uji hasil printing menggunakan CMM menghasilkan data posisi X,Y dan Z tiap titik pengukuran. Data tersebut diolah menghasilkan sembilan sebaran data hasil pengukuran pada tiap posisi. Keseluruhan data dari sepanjang $120 \mathrm{~mm}$ menghasilkan total 
error/penyimpangan ketelitian dimensi. Namun dalam pengukuran benda uji ada nilai uncertainty/ketidakpastian pengukuran.

\section{Langkah Pengujian}

1. Pengukuran pemosisian atau under no load ektruder sumbu X. Parameter gerak sumbu X ditentukan dengan kecepatan $50 \mathrm{~mm} / \mathrm{s}$, percepatan $1000 \mathrm{~mm} / \mathrm{s}^{2}$ dan jerk $7,5 \mathrm{~m} / \mathrm{s}^{3}$. Pengukuran under no load akurasi mesin FDM mengacu pada ISO 230-2 2006. Sumbu X ekstruder diukur sepanjang $120 \mathrm{~mm}$. Pada jarak tersebut dibagi menjadi 7 step pengukuran posisi setiap $20 \mathrm{~mm}$. Pengukuran dilakukan dua arah dari titik nol menuju $120 \mathrm{~mm}$ kemudian kembali lagi diukur dari titik $120 \mathrm{~mm}$ menuju titik 0 untuk mendapatkan nilai repeatability pada dua arah yang berbeda dan didapatkan nilai backlash. Pengukuran dilakukan dengan lima kali perulangan.

Kompensasi kontrol berupa pengaturan step/unit motor stepper sebesar 80,0, 80,1 dan 80,2 dijadikan variabel masukan untuk dilihat variabel keluarannya. Variabel keluaran dari pengukuran under no load adalah
1. $\mathrm{M}=$ Error posisi rata-rata
2. $\mathrm{E}=$ Error posisi sistematik
3. $\mathrm{R}+\quad=$ Mampu ulang arah gerak sumbu $\mathrm{X}+$
4. $\mathrm{R}-\quad=$ Mampu ulang arah gerak sumbu X-
5. $\mathrm{B}=$ Backlash maksimal pengukuran
6. $\mathrm{A}+\quad=$ Akurasi arah gerak sumbu $\mathrm{X}+$
7. A- $=$ Akurasi arah gerak sumbu X-
8. A $=$ Akurasi total dari pengukuran

2. Pengukuran benda uji hasil AM menggunakan mesin CMM. Benda uji dibuat dengan parameter proses printing yang mengacu pada penelitian Sanchez dkk (2014) dan dapat dilihat pada Tabel 2. Menurut Sanchez dkk (2014), parameter tersebut merupakan parameter optimal dalam pembuatan benda uji. Benda uji hasil printing dapat dilihat pada Gambar 4. Pengukuran ketelitian dimensi dilakukan sepanjang $120 \mathrm{~mm}$ pada benda uji printing. Benda uji diukur dimensinya setiap panjang $20 \mathrm{~mm}$ dengan 9 kali pengambilan data pada tiap sisi. Pengukuran dimensi dilakukan secara incremental dimulai dari sisi ukur 1 sampai dengan 7.

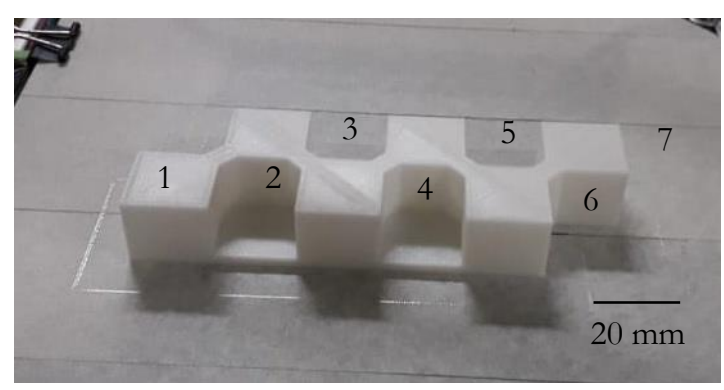

Gambar 4. Benda uji hasil printing 
A. T. Rohman et al. / Journal of Mechanical Design and Testing 2(1), (2020), 1-10

Tabel 2. Parameter proses printing benda uji(Sanchez dkk, 2014)

\begin{tabular}{lcl}
\hline \multicolumn{1}{c}{ Parameter } & Nilai & Satuan \\
\hline Layer thickness & 0,20 & $\mathrm{~mm}$ \\
Raster width & 0,71 & $\mathrm{~mm}$ \\
Suhu Bed & 60 & ${ }^{\circ} \mathrm{C}$ \\
Suhu Nozzle & 200 & ${ }^{\circ} \mathrm{C}$ \\
\# of perimeters & 3 & \\
Top solid layers & 3 & \\
Bottom solid layers & 3 & \\
Fill density & 30 & $\%$ \\
Material & PLA & \\
\# of repetitions & 2 & \\
Travel speed & 200 & $\mathrm{~mm} / \mathrm{s}$ \\
Nozzle diameter & 0,4 & $\mathrm{~mm}$ \\
Filament Diameter & 1,75 & $\mathrm{~mm}$ \\
Support & No & \\
Slicer & Repetier-Host & \\
& V2.05 & \\
\hline
\end{tabular}

\section{HASIL DAN PEMBAHASAN}

Konfigurasi pengukuran akurasi mesin FDM menggunakan laser interferometer dapat dilihat pada Gambar 5. Hasil pengukuran under no load menghasilkan data error posisi, mampu ulang, backlash dan akurasi sumbu X (ekstruder) mesin FDM dapat dilihat pada Tabel 3. Karakteristik penyimpangan sumbu x bernilai positif sebesar $137 \mu \mathrm{m}$ maka saat diberikan penambahan nilai step/unit motor sebesar 80,1 maka nilai penyimpangan naik sebesar $59 \mu \mathrm{m}$. Pada step/unit 80,2 maka terjadi peningkatan penyimpangan yang signifikan sebesar $214 \mu \mathrm{m}$. Terjadinya kenaikan hanya pada $\mathrm{R}+$ sebesar $13 \mu \mathrm{m}$ pada step/ unit 80,1.

Backlash tidak terperangaruh terhadap perubahan nilai step/unit. Error posisi rata-rata (M) mengalami kenaikan yang signifikan. Grafik penyimpangan pada sumbu X, Gambar 6, menunjukkan pola penambahan penyimpangan akurasi pada arah positif. Hal ini terjadi karena penambahan nilai step/unit motor secara aktual berpengaruh terhadap penambahan jarak pergerakan translasi sumbu $\mathrm{X}$.

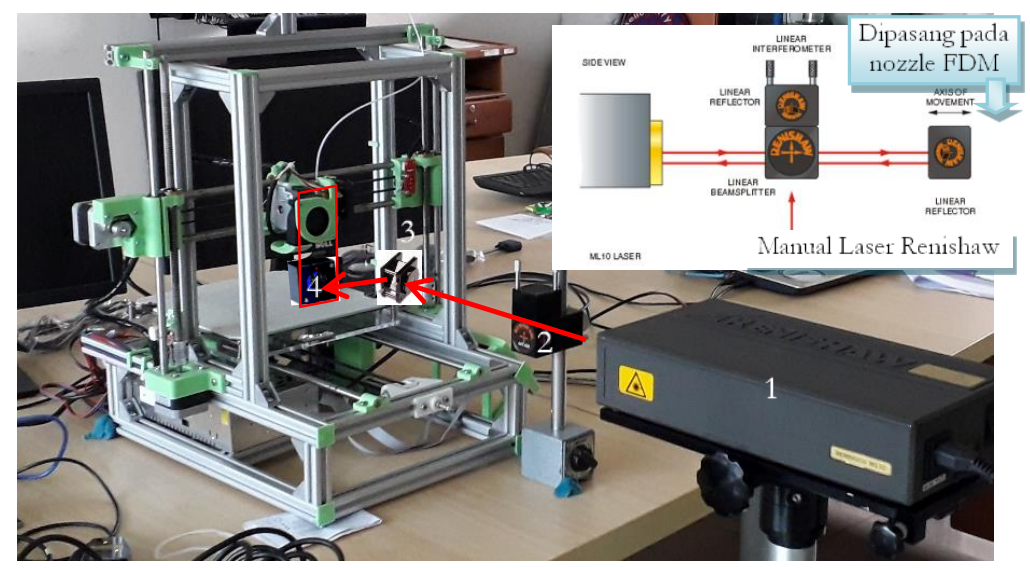

Gambar 5. Pengukuran akurasi mesin FDM
Keterangan gambar :

1. Laser Interferometer

2. Linear beamsplitter dan linear reflector

3. Mirror reflector

4. Linear reflector

Arah laser 

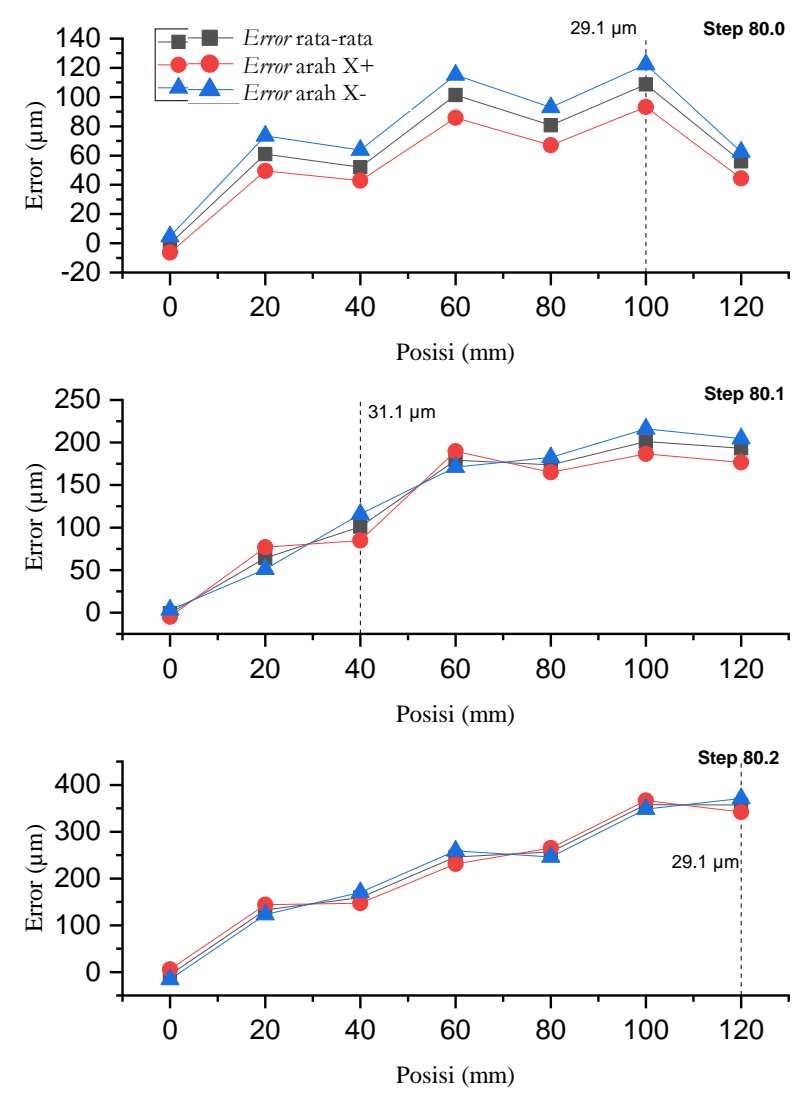

Gambar 6. Grafik akurasi under no load sumbu x (ekstruder)

Tabel 3. Data akurasi sumbu X (ekstruder) dengan variasi step/unit motor

\begin{tabular}{ccccccccccc}
\hline No & Sb & Step/Unit & $\begin{array}{c}\mathbf{M} \\
\mu \mathrm{m}\end{array}$ & $\begin{array}{c}\mathbf{E} \\
\mu \mathrm{m}\end{array}$ & $\begin{array}{c}\mathbf{R}+ \\
\mu \mathrm{m}\end{array}$ & $\begin{array}{c}\mathbf{R}- \\
\mu \mathrm{m}\end{array}$ & $\begin{array}{c}\mathbf{B} \\
\mu \mathrm{m}\end{array}$ & $\begin{array}{c}\mathbf{A}+ \\
\mu \mathrm{m}\end{array}$ & $\begin{array}{c}\mathbf{A}- \\
\mu \mathrm{m}\end{array}$ & $\begin{array}{c}\mathbf{A} \\
\mu \mathrm{m}\end{array}$ \\
\hline 1 & $\mathrm{X}$ & 80,0 & 109 & 123 & 15 & 13 & 21 & 115 & 123 & 137 \\
2 & $\mathrm{X}$ & 80,1 & 176 & 186 & 28 & 10 & 20 & 184 & 192 & 196 \\
3 & $\mathrm{X}$ & 80,2 & 329 & 344 & 12 & 9 & 21 & 331 & 343 & 351 \\
\hline
\end{tabular}

Hasil pengukuran ketelitian benda uji hasil printing dapat dilihat pada Tabel 4. Error posisi pada tiap sisi ukur ditunjukkan pada masing-masing nilai step/ unit motor. Ketelitian dimensi ditunjukkan dari besar total error akurasi produk. Error total atau ketelitian dimensi merupakan selisih nilai error terbawah terhadap error tertinggi. Total penyimpangan ketelitian dimensi benda uji pada step/unit 80,0 yaitu sebesar 0,302 mm. Ketidakpastian pengukuran sebesar $\pm 0,051 \mathrm{~mm}$ dengan interval kepercayaan $68 \%$ atau coverage factor satu. Total penyimpangan ketelitian dimensi benda uji pada step/unit 80,1 $120 \mathrm{~mm}$ turun menjadi 0,274 mm. Ketidakpastian pengukuran meningkat hanya sebesar $\pm 0,006 \mathrm{~mm}$ yang berarti tidak terlalu signifikan. Ketidakpastian 
ketelitian dimensi benda uji pada step/unit 80,2 bernilai $\pm 0,030 \mathrm{~mm}$ yang menunjukkan bahwa peningkatan step/unit dapat mengurangi ketidakpastian pengukuran. Total penyimpangan ketelitian dimensi menunjukkan nilai yang baik yaitu $0,157 \mathrm{~mm}$. Benda kerja dengan posisi 60 mm sampai dengan $120 \mathrm{~mm}$ mewakili titik tengah bed sampai dengan titik akhir bed mesin FDM. Maka area tersebut bisa menjadi rekomendasi posisi penempatan benda untuk proses printing dikarenakan nilai Maximum Percent Error (MEP) memiliki nilai yang relatif rendah pada area tersebut. Grafik penyimpangan ketelitian dimensi benda uji dengan variasi step/unit motor dapat dilihat pada Gambar 7.

Tabel 4. Data akurasi produk arah X dengan variasi step/unit motor

\begin{tabular}{|c|c|c|c|c|c|c|c|c|c|c|}
\hline \multirow{2}{*}{ No } & \multirow{2}{*}{ Keterangan } & \multirow{2}{*}{ Step/Unit } & \multicolumn{7}{|c|}{ Posisi } & \multirow{2}{*}{ Total Error } \\
\hline & & & $\overline{0}$ & $20 \mathrm{~mm}$ & $40 \mathrm{~mm}$ & $60 \mathrm{~mm}$ & $80 \mathrm{~mm}$ & $100 \mathrm{~mm}$ & $120 \mathrm{~mm}$ & \\
\hline 1 & Error posisi & 80.0 & $\overline{0}$ & 0.103 & 0.078 & 0.037 & -0.005 & -0.077 & -0.199 & \\
\hline 2 & Stdev & 80.0 & 0 & 0.03 & 0.039 & 0.051 & 0.014 & 0.041 & 0.025 & $0.302+0.051 \mathrm{~mm}^{*}$ \\
\hline 3 & MEP & 80.0 & 0 & $0.51 \%$ & $0.20 \%$ & $0.06 \%$ & $-0.01 \%$ & $-0.08 \%$ & $-0.17 \%$ & \\
\hline 4 & Error posisi & 80.1 & 0 & 0.195 & 0.124 & 0.105 & 0.064 & 0.028 & -0.079 & \\
\hline 5 & Stdev & 80.1 & 0 & 0.056 & 0.030 & 0.052 & 0.021 & 0.051 & 0.030 & $0.274+0.056 \mathrm{~mm}^{*}$ \\
\hline 6 & MEP & 80.1 & 0 & $0.96 \%$ & $0.31 \%$ & $0.17 \%$ & $0.08 \%$ & $0.03 \%$ & $0.07 \%$ & \\
\hline 7 & Error posisi & 80.2 & 0 & 0.151 & 0.111 & 0.146 & 0.122 & 0.107 & -0.006 & \\
\hline 8 & Stdev & 80.2 & 0 & 0.010 & 0.016 & 0.025 & 0.027 & 0.022 & 0.030 & $0.157+0.030 \mathrm{~mm}^{*}$ \\
\hline 9 & MEP & 80.2 & 0 & $0.75 \%$ & $0.28 \%$ & $0.24 \%$ & $0.15 \%$ & $0.11 \%$ & $-0.01 \%$ & \\
\hline
\end{tabular}

*interval kepercayaan $68 \%$ dengan coverage factor $: 1$

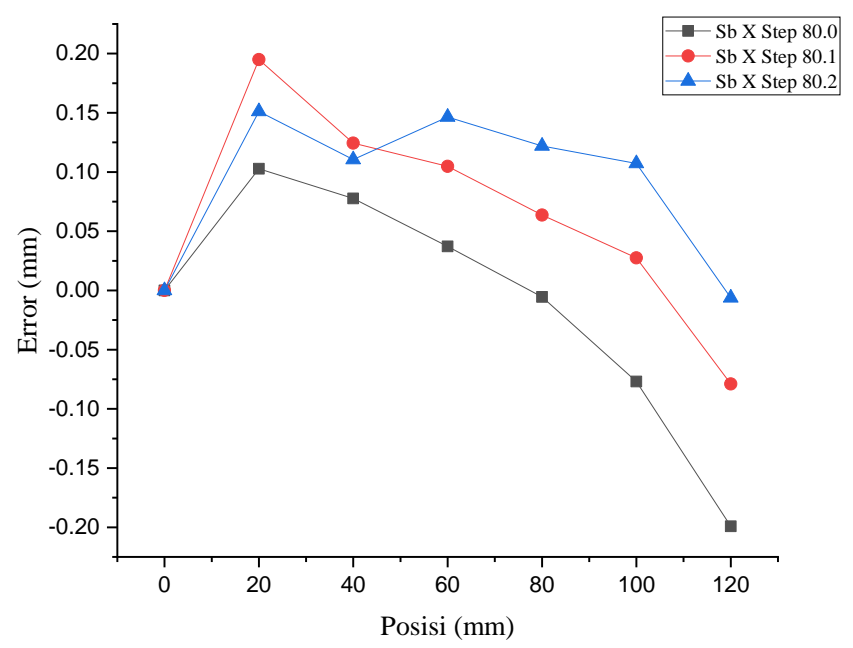

Gambar 7. Grafik penyimpangan ketelitian benda uji hasil printing sumbu x dengan variasi step/unit motor

Penyimpangan ketelitian dimensi benda hasil uji printing diawali adanya penyimpangan geometri yang bisa dievaluasi menggunakan pengukuran gerak under no load sumbu X ekstruder (Huang dkk, 2018). 
Terjadi adanya perbedaan nilai penyimpangan ketelitian dengan dua metode antara pengukuran gerak under no load dan pengukuran CMM benda uji hasil printing diakibatkan karena beberapa faktor. Pada pengukuran gerak under no load hanya dipengaruhi oleh faktor error yang diakibatkan oleh kendala mekanik seperti elastisitas timing belt, keausan guide rod dan keausan bushing sumbu X yang berakibat pada penyimpangan posisi (Qin dkk, 2019).

Pada pengukuran ketelitian benda uji printing menggunakan CMM dipengaruhi oleh faktor lain seperti shrinkage atau penyusutan material PLA akibat dari proses pendinginan. Benda uji hasil printing memiliki panjang $120 \mathrm{~mm}$. Shrinkage benda uji dengan nilai parameter 80,0 step/unit motor terjadi pada area $80 \mathrm{~mm}$ sampai dengan $120 \mathrm{~mm}$ dengan nilai 0,078 $\mathrm{mm}-0,194$ $\mathrm{mm}$. Benda uji sepanjang titik awal $0-60 \mathrm{~mm}$ tidak terjadi shrinkage. Shrinkage material berpengaruh terhadap pengurangan dimensi benda pada bidang printing arah sumbu X dan Y. Shrinkage dapat diperbaiki dengan metode SCF (Shrinkage Coefficient Factor). Namun efek perbaikan dengan SCF ini menyebabkan ketelitian dimensi menjadi besar yaitu sekitar 0,552/60 mm untuk material PLA (Abdi dkk, 2018).

Metode optimasi kontrol step/unit motor dapat meningkatkan ketelitian dimensi benda uji printing tanpa harus modifikasi G-Codes maupun modifikasi 3D model CAD seperti yang dilakukan oleh penelitian yang sudah ada (Cajal dkk., 2016).

\section{KESIMPULAN}

Penelitian dengan membandingkan pengukuran under no load pada mesin FDM terhadap pengukuran pada benda hasil uji printing memiliki perbedaan hasil. Pengukuran under no load adalah pengukuran akurasi gerak sumbu X. Hal ini dikarenakan adanya faktor shrinkage pada material PLA, faktor . Akurasi pada hasil pengujian dapat disimpulkan bahwa:

1. Naiknya repeatability pada pergerakan ekstruder akan berpengaruh terhadap peningkatan nilai ketidakpastian hasil pengukuran benda uji printing namun dengan nilai yang sangat kecil yaitu $6 \mu \mathrm{m}$. Sedangkan turunnya repeatability berpengaruh terhadap turunnya nilai ketidakpastian dimensi hasil printing.

2. Penambahan nilai step/unit dari 80,0 sampai dengan 80,2 menyebabkan sistematik error gerak under no load meningkat sebesar $0,214 \mathrm{~mm}$.

3. Penambahan nilai step/unit dari 80,0 sampai dengan 80,2 menyebabkan total error atau ketelitian dimensi benda uji meningkat sebesar $0,145 \mathrm{~mm}$.

4. Nilai shrinkage diukur dari selisih akurasi ketelitian dimensi terhadap akurasi gerak ekstruder under no load. Berbeda dengan perhitungan shrinkage secara umum yang menghitung shrinkage sebagai perbedaan nilai ketelitian dimensi benda uji terhadap dimensi nominal desain CAD.

5. Akurasi gerak ekstruder berbanding terbalik dengan akurasi ketelitian dimensi benda uji. Hal ini dipengaruhi oleh mesin faktor penyusutan material PLA.

6. Kecepatan feeding dan diameter nozzle ditetapkan pada nilai tertentu sehingga bukan menjadi variabel yang dicari pengaruhnya terhadap ketelitian gerak mesin dan produk benda uji. 


\section{DAFTAR PUSTAKA}

Abdi, Z., Alyasseri, A., Khader, A. T., Al-Betar, M. A., Papa, J. P., Alomari, O. A. and Makhadmeh, S. N. 2018. Analysis of Shrinkage Compensation Factor (SCF) of FDM uPrint SE for Accuracy Enhancement. International Journal of Integrated Engineering, 10(7), pp. 102-116.

Begović, E., Plančić, I., Ekinović, S. and Ekinović, E. 2014. Laser Interferometry Measurement and Calibration Method for Machine Tools. 3rd Conference "MAINTENANCE 2014", (September 2015), pp. 19-28.

Berman, B. 2012. 3-D printing: The new industrial revolution, Business Horizons. Kelley School of Business, Indiana University. 55(2), pp. 155-162.

Cajal, C., Santolaria, J., Samper, D. and Velazquez, J. 2016. Efficient volumetric error compensation technique for additive manufacturing machines. Rapid Prototyping Journal, 22(1), pp. 2-19.

Cruz Sanchez, F. A., Boudaoud, H., Muller, L. and Camargo, M. 2014. Towards a standard experimental protocol for open source additive manufacturing: This paper proposes a benchmarking model for evaluating accuracy performance of 3D printers. Virtual and Physical Prototyping, 9(3), pp. 151-167.

Huang, Z., Dantan, J. Y., Etienne, A., Rivette, M. and Bonnet, N. 2018. Geometrical deviation identification and prediction method for additive manufacturing. Rapid Prototyping Journal, 24(9), pp. 1524-1538.

Qin, Q., Huang, J. and Yao, J. 2019. A real-time adaptive look-ahead speed control algorithm for FDM-based additive manufacturing technology with Hbot kinematic system. Rapid Prototyping Journal, 25(6), pp. 1095-1107. doi: 10.1108/RPJ-11-2018-0291.

Sadia, M., Alhnan, M. A., Ahmed, W. and Jackson, M. J. 2017. 3D printing of pharmaceuticals. Micro and Nanomanufacturing, 2, pp. 467-498. doi: 10.1007/978-3-319-67132-1_16.

Schniederjans, D. G. and Yalcin, M. G. 2018. Perception of 3D-printing: analysis of manufacturing use and adoption. Rapid Prototyping Journal, 24(3), pp. 510-520. doi: 10.1108/RPJ-04-2017-0056.

Valerga, A. P., Batista, M., Salguero, J. and Girot, F. 2018. Influence of PLA filament conditions on characteristics of FDM parts. Materials, 11(8), pp. 2018-2022. 